\title{
Characteristics of the roles of mothers of children with intellectual disabilities as a basis for their individual therapy
}

\author{
Marcin Białas \\ Department of Pedagogy and Occupational Therapy, \\ Gdansk University of Physical Education and Sport, Gdansk, Poland
}

\section{abstract}

Background: Women enjoy a variety of social roles during their lives. Among the commonly known ones, which include e.g. the roles of wives and mothers, there are also those that radically change the scenario of one's past life. These include the role of mothers of children with intellectual disabilities. After all, the hardships associated with caring for them and with their upbringing, influence their mothers' perception of the world, change the existing family and professional social relations, determine the choice of values, and limit or block the goals set to date. It seemed interesting to the author of the study to recognise the roles of mothers of children with intellectual disabilities.

Material and methods:

Their categorisation revealing the nature of a given role was possible owing to the conducted research. It was attended by 104 mothers of children with intellectual disabilities who answered a series of questions included in the interview questionnaires. A hermeneutical analysis of their answers made it possible to describe a given role in detail. Among these four can be distinguished which are conventionally defined as: "REBEL", «RATIONALIST", "SHAM" and "RESOURCEFUL".

Results: These roles are fundamentally different from each other, indicating the traits that characterise mothers bringing up children with intellectual disabilities. Identifying oneself with one of them may show both the desired features of the role played and indicate the destructive elements which negatively determine the course of their previous lives.

Conclusions: This is the basis for personalised therapy dedicated to mothers of children with intellectual disabilities.

Key words: child with intellectual disability, mother, social roles, therapy.

\section{article details}

Article statistics:

Full-text PDF:

Copyright Indexation:

Funding:

Conflict of interests: Corresponding author:

Open Access License:

Word count: 12,470; Tables: 2; Figures: 0; References: 33

Received: October 2020; Accepted: February 2021; Published: March 2021

http://www.balticsportscience.com

(c) Gdansk University of Physical Education and Sport, Poland

Celdes, Clarivate Analytics Emerging Sources Citation Index (ESCI), CNKI Scholar (China National Knowledge Infrastructure), CNPIEC, DOAJ, EBSCO - Central \& Eastern European Academic Source, EBSCO - SPORTDiscus, EBSCO Discovery Service, Google Scholar, Index Copernicus, J-Gate, Naviga (Softweco, Primo Central (ExLibris), ProQuest - Family Health, ProQuest - Health \& Medical Complete, ProQuest - Illustrata: Health Sciences, ProQuest Nursing \& Allied Health Source, Summon (Serials Solutions/ProQuest, TDOne (TDNet), Ulrich's Periodicals Directory/ ulrichsweb, WorldCat (OCLC)

This research received no specific grant from any funding agency in the public, commercial, or not-for-profit sectors. Author has declared that no competing interest exists.

Marcin Białas, Department of Pedagogy and Occupational Therapy, Gdansk University of Physical Education and Sport, 80-336 Gdansk, Poland; e-mail: marcin.bialas@awf.gda.pl; ORCiD: 0000-0003-0160-1839

This is an open access article distributed under the terms of the Creative Commons Attribution-Non-Commercial-NoDerivatives 4.0 International (https://creativecommons.org/licenses/by-nc-nd/4.0/), which permits use, distribution and reproduction in any medium, provided the original work is properly cited, the use is non-commercial and is otherwise in compliance with the license. 


\section{INTRODUCTION}

For most parents, the birth of a child is an important life event. The appearance of a new creature who is wanted, expected, and healthy, awakens joy and happiness. Even though it is necessary to fundamentally reorganise one's life, entering into the new social roles of a mother and father, this event is interpreted in a positive light as a pleasant, unique and valuable life experience.

Such an optimistic picture is obscured by the fact that a child with a disability is born. It is well known that every disability of a child, even the smallest one, is the cause of many worries for parents. Therefore, it would seem that it does not matter what kind of disability is involved. All children with sensory impairments, i.e. blind and near-blind as well as deaf and near-deaf, with physical or mental disabilities, chronically ill or with a complex or conjugated combination of these, become a cause of special concern for parents [1].

However, there is a widespread belief in society that it is the child's intellectual disability, his or her mental retardation, especially in its deeper forms, that is one of the causes of particularly strong, negative experiences for parents [2, 3]. This is, of course, related to the symptoms of developmental disorders, characteristic of intellectual disabilities, as well as rejection attitudes of the social environment, resulting from the lack of acceptance of these children. Sometimes manifesting even a clear aversion and prejudice towards them and their parents [4].

It is not uncommon for parents of children with intellectual disabilities to encounter stigmatisation and humiliation, often caused by a deformed or unaesthetic appearance of their children and the shame they feel about it [3], by their "strange" or "abnormal" behaviour by which they clearly distinguish themselves from their "normal peers" [5] or by a lack of control over one's own physiology, often causing anxiety and sometimes even disgust in the "healthy" part of society [6]. These are a result of mental confrontation of the ideal of man - his or her fullness of humanity - with the "deficient" image of a "quasiman", further strengthened by the fact that you are dealing with a physically mature person who remains at the level of development of a small child regardless of his or her age. It is the aforementioned deficits of children with intellectual disabilities, combined with the Cartesian attribution of the main role to the rational human mind as the most important human value, that are a reason for the changes taking place in the family $[7,8,9]$.

The birth of a child with intellectual disabilities destroys not only his/her parents, but the entire family system. This translates into an inevitable crisis of this system, resulting in a high risk of dysfunction, pathology and even total family breakdown. The helplessness, conflict-proneness, coercion, resignation or struggling with tensioning problems, as well as the constant confrontation with suffering and disillusionment, which has been incorporated into the everyday life of these families, undermine the value of the truths established by logic [10]. A child's disability entering the family evokes horror, creates a sense of tragedy because of its mysterious, unfathomable origins, its absurdity and inevitability and the helplessness it experiences [11]. It disturbs the past image of the family and dismantles the stabilised way of its functioning. Finally, causes profound emotional and social change, affecting both its internal and external family relationships [12]. In this case, a child's disability becomes a burden that poses risks not only to his or her family as a whole, but also to individual members of the family. This is shown in the roles created by parents where their child with intellectual disability becomes a focal point. At this point it seems interesting to recognise the roles played by mothers of children with intellectual disabilities and to categorise and describe them as the aim of the research undertaken. The author of the study puts forward a thesis that this is not only possible but also helpful in conducting individual therapy dedicated to this group of people. The remainder of this paper is an explication of this thesis [13]. 


\section{MATERIAL AND METHODS}

Initially, it was assumed that the survey would involve 200 people (mothers of children with intellectual disabilities) who were recruited using snowball sampling [14] by 18 volunteers participating in the survey. Unfortunately, many mothers refused to participate. The most important reasons for refusing to take part in the survey were found to be: lack of time, too personal or - and I quote - "too depressing" questions in the interview questionnaire. In the end, 104 mothers of children with intellectual disabilities took part in the survey, representing $100 \%$ of the population studied.

Important variables taken into account when interpreting the results of the research were: the age of the surveyed mothers, their education, their marital and legal situation, their professional situation, the number of children raised, as well as their age, disorders causing intellectual disabilities, the degree of intellectual disability, having additional diseases, and the child's form of education.

For empirical analysis and verification of the presented hypothesis, the method of hermeneutical analysis of statements was used (Greek 'ermeneuo' means 'interpret', 'explain', 'express', 'translate'). The rationale for choosing this research method was the possibility of an analytical insight into the mothers' statements. Firstly, this enabled dividing the population according to the assumed role of the mother of a child with an intellectual disability. This division was made both on the basis of an assessment of the examined mothers' statements as well as their reactions and behaviour observed by the volunteers. Therefore, it is another diagnostic element of a hermeneutic interpretation. Secondly, the application of this method also gave an opportunity to subjectively assess the experiences of the examined mothers. Thirdly, the hermeneutic method also strengthens the practical side of action, strengthens praxis, and therefore the very conversation with the mothers participating in the research, speaking about their experiences - the hardships of life associated with raising a child with intellectual disabilities - in itself was of a therapeutic value [15].

The technique used in the research was an interview with the mothers of children with intellectual disabilities, stimulated by a volunteer whose task was to talk to the mothers about the topics included in the interview questionnaires, observe them while answering individual questions, or possibly give instructions on how to fill them in or take notes of their answers. The volunteers also had an important task to make possible comments, mark the para-linguistic properties of the speech, describe their behaviour, facial expressions, etc. during the interview in order to achieve the so-called "fusion of the horizons of cognition" (a fusion of two horizons: the interviewed mother and the interviewer) in order to best interpret the collected data, understand the hidden meaning, subtext of meaning and self-reflection.

The research tool was an original interview questionnaire. Consisting of eight parts: the first two were so-called metrics containing the sociometric data of the mother (DM) and her mentally disabled child, the third part contained a collection of unfinished sentences for a deep understanding of the needs, problems and motivations of the examined mothers, entering the skin of the examined person modelled on the so-called map of empathy used in the Design Thinking Method by David Kelley [16].

The fourth part included questions for measuring existential trauma, the next four parts contained sets of open-ended questions, oscillating around issues related to the birth of an intellectually disabled child, its care and upbringing, rehabilitation problems and educational problems.

At this point, it is worth noting that due to the vastness of the interview questionnaires, the interviewed mothers had unlimited time to meet with the volunteer conducting the 
survey. His role, in accordance with the surveyed mothers' wishes, could consist both in observing the mothers who wrote down their own answers to the individual questions and in noting the answers they gave. The mothers could interrupt the meeting at any time and arrange for it to continue anywhere and anytime.

It is well known that in the course of life a person takes on a certain role, which, with the most commonly used theatrical metaphor, can be interpreted as becoming a kind of social actor, playing their roles resulting from their position and expectations towards individuals or groups. The scenario of these roles is not infrequently widely recognised, defined as a system of relatively permanent behaviours expressing the needs and expectations towards those before whom they are played, leaving the "actor" a certain margin of free interpretation as to his or her own ideas and ways of performing a given role [17].

Among the numerous creations that man plays, there are those that he or she usually undertakes in a conscious and purposeful manner. Deciding to start a family, people naturally take on the role of a wife or a husband and then a mother or father. There are also those that are undertaken independently of the "actor's" will, often radically changing the usual and universally known pattern of action. These include the roles of mothers and fathers of children with intellectual disabilities [18].

It is clear that the change in the role of the parents of a child to that of the parents of a child with intellectual disability affects both mothers and fathers and does not determine the choice of one of them. However, as a result of the cultural model of family functioning, it is the women/mothers who are responsible for housekeeping and childcare, and the men/fathers who earn money to support them. At the same time, taking into account economic motives revealing the statistical imbalance between the wages of women and men, it is the role of the mother of a child with intellectual disability that becomes more pronounced in this case. This is manifested not only by a characteristic attitude towards her child with intellectual disability, which is often enhanced by an unreasonable sense of guilt that she feels in connection with the child's health condition. In addition, this relationship is associated with a strong need to compensate for the harm suffered by the child, to improve his or her fate, or to do something about it. Another issue is the already different attitude to her own life, which consists in rejecting her previously favoured values, giving up her goals, desires or expectations [19, 9].

\section{ROLES OF MOTHERS OF CHILDREN WITH INTELLECTUAL DISABILITIES REVEALED IN ORIGINAL RESEARCH}

Recognition of these roles assumed by mothers of children with intellectual disabilities became the aim of the research undertaken, with 104 mothers making up $100 \%$ of the study population. The study comprised a hermeneutical analysis of original interview questionnaires, and observations of the interviewed mothers showed subtle differences noticeable at the level of emotional element (visible in the vocabulary used and the form of text notation), behavioural element (observed in the behaviour described by the volunteers conducting the interviews), and axiological element (showing the attitude of the questioned mothers to the assumed values). Thus allowing an attempt to categorise and describe the roles they assume in relation to their children with intellectual disabilities.

The analysis of the collected research material allowed the examined mothers to be assigned to four groups, showing the specific roles they play towards their children with intellectual disabilities. These roles were given symbols R1, R2, R3, R4. It should be noted here that not every analysed case made it possible to clearly qualify mothers to a particular group representing a particular role. Some statements contained in the interview questionnaires indicated the so-called "mixed role", which is a compilation of 
characteristic features of the others. However, in these few, because in only 7 cases out of 104 respondents (7\% vs. 93\%), the majority criterion was applied (more characteristic features of a given role), allowing for their adequate assignment.

On this basis, the study population was divided into groups according to the represented roles. Hence, the R1 group consisted of 14 mothers, i.e. $13.5 \%$ of the studied population. A group of 28 mothers, representing $26.9 \%$ of the population, was marked with the R2 symbol. The R3 group included 25 mothers, accounting for $24 \%$. Whereas the R4 group was represented by 37 mothers comprising $35.6 \%$ of the population.

\section{Characteristics OF the ASSUMEd ROLES OF MOTHERS OF CHILDREN WITH INTELLECTUAL DISABILITIES ON THE BASIS OF THE COLLECTED STATISTICAL DATA}

An interesting picture of the roles of mothers of children with intellectual disabilities can also be sketched out on the basis of the statistical summary of the collected data. Its detailed analysis indicates that there were 14 women in the group of mothers identified by the R1 symbol, which represents $13.5 \%$ of the total population. This group was the least numerous. It was mainly represented by 6 mothers between 41 and 50 years of age, which is $5.8 \%$ of the respondents and another 5 , which is $4.8 \%$ of the population aged 31 40 years. The surveyed women usually had a university degree, as this was declared by 8 mothers, representing $7.7 \%$ of the surveyed population, and by 6 mothers with secondary education, representing $5.8 \%$ of the surveyed population. It should be added here that none of the mothers belonging to this group had either primary or vocational education, which may be one of the aspects characteristic of this group. In the vast majority of cases, i.e. as many as 12 cases, which accounted for $11.6 \%$ of the respondents, this group consisted of women who were not professionally employed. None of these mothers have sought work. This aspect can also be a distinguishing feature of the group. Taking into account the current private situation of the mothers representing this group, they were mainly married; such a declaration was made by 8 women, i.e. $7.7 \%$. Only 4 of this group were in a civil partnership, which represents $3.8 \%$ of the studied population. From the collected data we can also find out that the mothers being characterised mostly have one child, as indicated by 7 of them, representing $6.7 \%$ of the respondents, and two children, as declared by 5 of them, representing $4.8 \%$ of the population. Their children were predominantly of school age, i.e. from 10 to 19 years of age, as indicated by 7 mothers, representing $6.7 \%$ of the surveyed, or of preschool and early school age, i.e. from 3 to 9 years of age. This was the answer given by 6 mothers, representing $5.8 \%$ of the population surveyed. Primarily with genetic disorders, as stated by 7 mothers, representing $6.7 \%$ of the respondents, demonstrating mainly moderate mental retardation, as confirmed by 10 mothers, or $9.6 \%$ of the respondents. The child of none of the mothers examined had a profound mental handicap. Moreover, in this group, 8 mothers, representing $7.7 \%$ of the population, indicated that their child does not have additional conditions, while the remaining 6 , representing $5.8 \%$ of the respondents, indicated that their child has one. At this point it should be added that no mother of this group has left this question unanswered, which may indicate a great deal of knowledge of the nature of her children's disabilities. The surveyed mothers mainly send their children to special schools - such answers were given by 7 mothers, representing $6.7 \%$ of the surveyed population, and integrated schools as declared by 5 mothers, representing $4.8 \%$ of the population.

The R2 group was represented by 28 women, representing $26.9 \%$ of the total population. Statistically speaking, these were the oldest women. 10 of them, representing $9.6 \%$ of the surveyed population, were in the 51-60 age range. Another larger group consisted of 9 mothers, i.e. $8.7 \%$ of the respondents, who were between $41-50$ years old. These were mostly women with secondary education, as declared by 14 of them, which represents $13.5 \%$ of the respondents, and women with tertiary education, which concerned 12 more 
mothers, representing $11.5 \%$ of the population. None of the mothers representing this group had primary education. The vast majority of these were working women, as indicated by the responses of 15 of them, which represents $14.4 \%$ of the surveyed population. Here it should be added that although in this group of mothers there were those not working, namely 8 of them, which is $7.7 \%$ of the respondents, the fact of being professionally active and the declaration of willingness to find a job for themselves is a distinguishing feature of this group of respondents. Although as many as 12 of them, representing $11.5 \%$ of the respondents, showed that they were married, the fact that almost all (except for being a widow) of the possible answers were chosen indicates that, in comparison with other groups of mothers, they are also in a different marital status. Undoubtedly, a characteristic feature of this group of respondents is the number of children raised. 15 mothers from the same group, representing $14.4 \%$ of the surveyed population, indicated that they were raising three or more children, which clearly distinguishes them from other groups. Their children were mainly of school age, as indicated by 16 of them, representing $15.3 \%$ of the population, as well as of pre-school and early childhood age, as declared by 11 of them, i.e. $10.6 \%$ of the respondents. Equally numerous groups of 10 mothers, representing $9.6 \%$ each, declared that their children mainly suffered from genetic and neurological disorders, causing moderate mental retardation. This is the answer given by the majority, i.e. 16 mothers, which represents $15.3 \%$ of the population surveyed. Comparable answers concerning the incidence of additional conditions in their children were given by two groups of a similar size. The first one was 15 mothers, i.e. $14.4 \%$ of the population surveyed, who stated that their children did not have any. The second group consisted of the remaining 13 mothers, i.e. $12.5 \%$ of the studied population, who were those declaring the occurrence of such diseases in their children. It is important to note at this point that none of the mothers representing this group of respondents left this question unanswered, which, as in the characteristics presented above, can prove that they are aware of their children's problems and have an open declaration taking into account such problems. The surveyed mothers revealed that their children mainly attended special education facilities, as indicated by 13 of them, i.e. $12.6 \%$ of the examined population, and integrated institutions, as declared by 10 mothers, i.e. $9.6 \%$ of the examined population.

The group marked R3 was represented by 25 mothers, representing $24 \%$ of the studied population. Statistically speaking, it was a group made up of the youngest women, because 10 of them, representing $9.6 \%$ of the respondents, were aged 41-50. However, two further groups were made up of six mothers each, representing $5.8 \%$ of the population, aged 25 30 and 31-40 years with secondary education, as indicated by the majority of mothers, i.e. 15 , which represents $14.4 \%$ of the studied population. The vast majority of these were non-working mothers - 22 of them gave such answers, representing $21.1 \%$ of the respondents. Statistically, this group composed of married women represented the highest percentage given its size. As many as 19 of them, representing $18.1 \%$ of the respondents, made such a declaration. This feature seems to be characteristic of this group. The largest number of mothers, as many as 15 , or $14.4 \%$ of the respondents, had one child. The remaining 10 mothers, i.e. 9.6\% declared that they had two children. None of the surveyed mothers in this group had three or more children. Statistically, the surveyed mothers also had younger children. 14 of them, representing $13.5 \%$ of the population, had pre-school and early childhood children, i.e. from 3 to 9 years old. The remaining 11 mothers, representing $10.6 \%$ of the population, had children of school age, i.e. from 10 to 19 years old. Taking into account the cause of their children's intellectual disabilities, as many as 12 mothers indicated neurological disorders, which account for $11.5 \%$, and genetic disorders, the most frequent contributor, according to eight respondents, i.e. $7.7 \%$ of the population in question, to a moderate degree of mental retardation, and according to seven more mothers, which accounts for $6.7 \%$, to a significant degree of mental retardation. Undoubtedly a significant feature of this group of surveyed mothers is 
the noticeable lack of answers to the question of the occurrence of additional conditions in their children, in as many as 20 cases, which represents as much as $19.2 \%$ of the surveyed population. The remaining 5 mothers, i.e. $4.8 \%$ of respondents indicated that their children do not have any. These figures are puzzling. Firstly, because the interviewed mothers representing this sample indicated the existence of such conditions when answering the interview questionnaires. Secondly, some of them have children with Down's syndrome, for example, which is characterised by a set of defects. Such a declaration by respondents raises further doubts about the form of education of their children. Although the largest number of them, as many as nine, or $8.7 \%$ of the population, indicated that their children attend mass institutions, and at the same time constituted the largest group among all the surveyed mothers, as many as eight more mothers representing this group, or $7.7 \%$ of those surveyed, declared that their children benefit from individual teaching, which stands in opposition to their earlier declaration that there are no additional conditions in their children or their desire to remain silent. This is because individual teaching is granted to sick children whose state of health makes it impossible or significantly difficult for them to take part in classroom activities.

The most numerous group, consisting of 37 mothers, representing $35.6 \%$ of the surveyed population, were those identified by symbol R4. Taking into account the age criterion, as many as 13 mothers, or $12.4 \%$ of the population, were aged $41-50$. The second largest population was made up of 11 mothers, i.e. $10.6 \%$ between 31 and 40 years of age. In this group there was also 1 mother who was over 61 years old, which is $1 \%$ of the respondents. The largest number of mothers, as many as 18 , i.e. $17.3 \%$ of the population described above, had primary education. The second largest group of 11 mothers, representing $10.6 \%$ of the respondents, were those with secondary education. None of the surveyed women representing this group had a university degree. Although 25 of them, or $24 \%$, were unemployed, the 12 others, or $11.5 \%$, were active in the labour market, putting this group of women second in terms of this very criterion. Given the current family situation of the surveyed mothers, the distribution of data is interesting. 20 of them, representing $19.3 \%$, are married. However, as many as 10 women from this group, which accounts for $9.6 \%$ of those surveyed according to the declaration, are single, which may be a characteristic of the population being described. Most of them have two children. This was the answer given by 25 women, i.e. $24 \%$ of the respondents. A large part in this respect was made up of 10 more, i.e. 9.6\% with three or more children. Comparably 14 mothers in each , which is $13.5 \%$ of the population each, have children of both preschool age and already adults over 19 years old. Although as many as 14 mothers, or $13.5 \%$ of those surveyed, had children with severe and moderate intellectual disabilities, as indicated by 11 of them, i.e. $10.6 \%$, this group of mothers included the largest number of those, namely 7 , who had children with profound intellectual disabilities, while at the same time constituting $6.7 \%$ of the respondents. In the vast majority of cases, in as many as 30 cases, the surveyed mothers did not answer the question about the child's additional conditions, which represents $28.8 \%$ of the population. The remaining 7 , representing $6.7 \%$ of the respondents, showed that their children did not have such conditions. This data seems to blur the real picture of the health of their children. As in the characteristics of the previous group, this is either due to the ignorance of the respondents, a desire to conceal this fact, or, most likely, the failure to notice such additional conditions in their children or to treat them in a way that is naturally (inseparably) linked to the disability in question. Comparable values relate to the declaration of the form of education of children. 14 mothers declared that their children participate in occupational therapy workshops, representing $13.5 \%$ of the surveyed population. Another large group of 13 mothers, i.e. $12.5 \%$, are those whose children attend special education facilities. There were also 2 mothers in this group, which represents $1.9 \%$ of the studied population, whose children do not participate in any form of education due to their age or health condition. 


\section{RESULTS}

A detailed description of all four roles, based on a selection of the most significant elements contained in the statements of the questioned mothers of children with intellectual disabilities and their observations, is presented in the table below (Table 1). The table includes research carried out at:

- the emotional level, expressed in specific vocabulary and form of expression;

- the behavioural level, based on observations of the examined mothers whose specific type of behaviour was recorded at the time of their response;

- the axiological level, containing a set of preferred values of the examined mothers, which were selected on the basis of the analysis of the texts of the interview questionnaires filled in by them.

Table 1. Subjective characteristics of the assumed roles of mothers of children with intellectual disabilities

CHARACTERISTICS OF THE ASSUMED ROLE

EMOTIONAL LEVEL

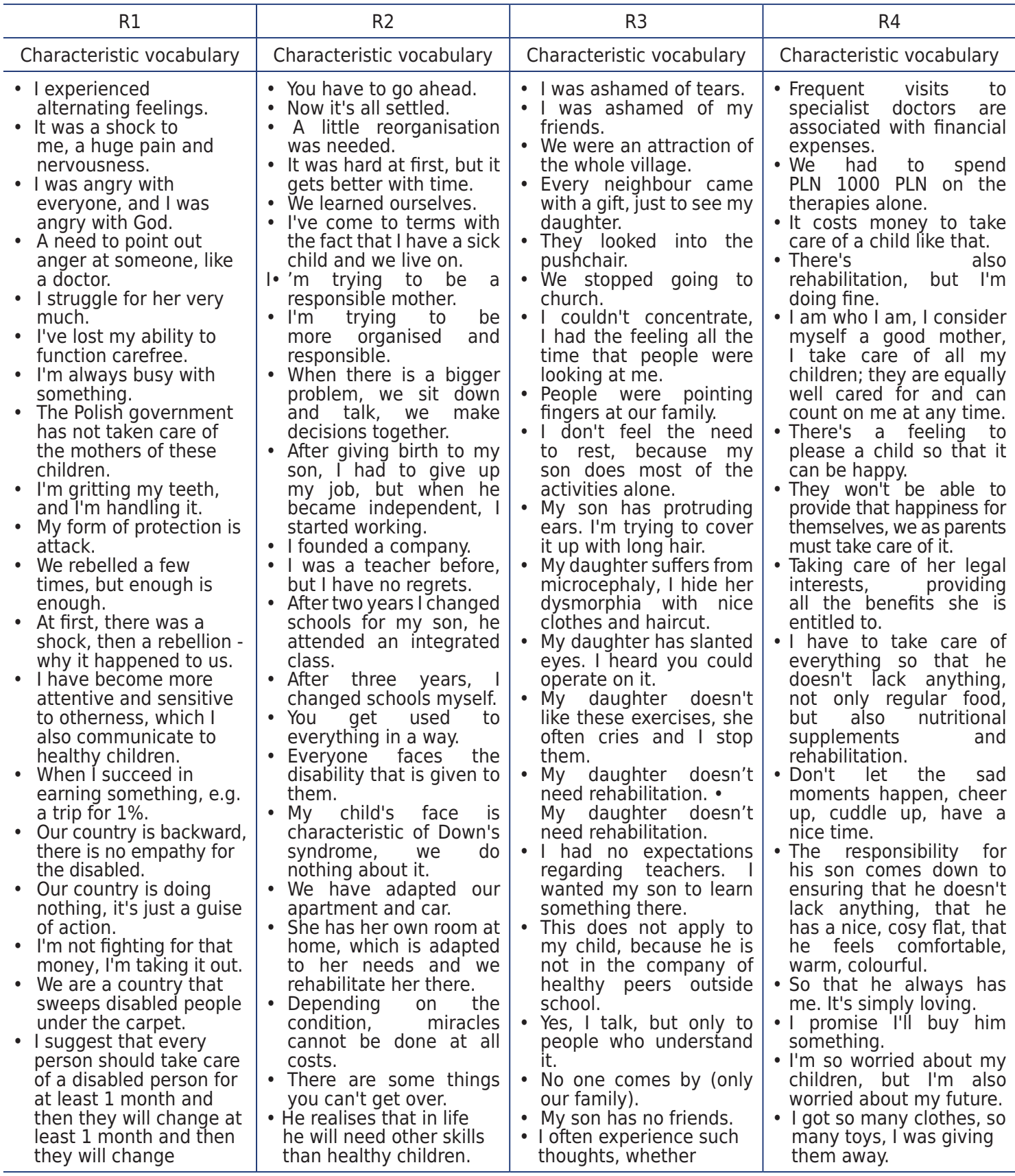




\begin{tabular}{|c|c|c|c|}
\hline R1 & $\mathrm{R} 2$ & R3 & R4 \\
\hline
\end{tabular}
important not to suffer.

- For the sake of emphasis, the words are written in capita letters.

- Often used exclamation marks and highlights.

- Used plural, e.g. our children.

- Extensive statements.

- Statements with comments (often critical) to the interviewers or survey creators.

- Rhetorical character of expression.

\section{Characteristic form of expression}

- Longer expressions.

- The tone of the speech is calm, balanced, not very emotional.

- The statements contain a charge of optimism, an open perspective, an idea for solving the problem.

- Balanced statements, based on previous considerations.

- She's speaking slowly, realistically.
- Shorter utterances.

- She often changes her mind.

- She blurs the text makes corrections.

- She censors her answers.

- She's wondering before answering.

- Often the speech takes the form of an official announcement.
Shortest utterances.

- Curt utterances.

- Often taking the form of sentence equivalents.

- Often the statements are reduced to single words (yes, no). 


\begin{tabular}{|c|c|c|c|}
\hline \multicolumn{4}{|c|}{ BEHAVIOURAL LEVEL } \\
\hline \multicolumn{4}{|c|}{ Characteristic behaviour } \\
\hline $\mathrm{R} 1$ & $\mathrm{R} 2$ & R3 & R4 \\
\hline $\begin{array}{l}\text { - } \text { Energetic. } \\
\text { - } \text { Temperamental. } \\
\text { answering. } \\
\text { - Prone to tears. } \\
\text { - She raises the tone of } \\
\text { her voice. } \\
\text { - She is characterised by } \\
\text { alternating emotional } \\
\text { reactions. } \\
\text { - She seems lonely, often } \\
\text { despite the fact that } \\
\text { she has a relationship. }\end{array}$ & $\begin{array}{l}\text { - Subdued. } \\
\text { - Calm. } \\
\text { - Insular. } \\
\text { - Peaceful. }\end{array}$ & $\begin{array}{l}\text { - Stodgy in a relationship. } \\
\text { - She can't distance } \\
\text { herself, "chill out". } \\
\text { - She pays attention to } \\
\text { how she sits down. } \\
\text { - She's correcting the } \\
\text { outfit. } \\
\text { - She's trying to make a } \\
\text { good impression. }\end{array}$ & $\begin{array}{l}\text { - She seems like she's } \\
\text { late. } \\
\text { - She can't sit still. } \\
\text { - Often peeking at her } \\
\text { watch. } \\
\text { - Clearly bored during the } \\
\text { survey. } \\
\text { - Honest in her } \\
\text { statements. } \\
\text { - Often referred to as } \\
\text { "hen" or "the Polish } \\
\text { mother" in a positive } \\
\text { sense. } \\
\text { - Whole-hearted, most } \\
\text { natural. }\end{array}$ \\
\hline \multicolumn{4}{|c|}{ AXIOLOGICAL LEVEL } \\
\hline \multicolumn{4}{|c|}{ Preferred values } \\
\hline $\begin{array}{l}\text { - Child's best interests. } \\
\text { - Family. } \\
\text { - Freedom. } \\
\text { - Responsibility. } \\
\text { - Dignity. }\end{array}$ & $\begin{array}{l}\text { - Child's best interests. } \\
\text { - Health. } \\
\text { - Family. } \\
\text { - Wisdom. } \\
\text { - Having a goal. }\end{array}$ & $\begin{array}{l}\text { - Child's best interests. } \\
\text { - Health. } \\
\text { - Family. } \\
\text { - Love. } \\
\text { - Peace. }\end{array}$ & $\begin{array}{l}\text { - Child's best interests. } \\
\text { - Family's best interests. } \\
\text { - Health. } \\
\text { - Dwelling. } \\
\text { - Work. } \\
\text { - Money. }\end{array}$ \\
\hline
\end{tabular}

Source: own elaboration.

The analysis of the collected material made it possible to adopt a conventional name alongside the symbol used to define a given group of mothers (R1, R2, R3, R4), representing specific features of the role they have assumed in relation to their children with intellectual disabilities. This enables illustrating the particular scheme of their role in an even more visible, symbolic and more eloquent way. At this point it should be stressed that in no way should the conventional terms used to define the roles concerned be read pejoratively. They are only a conventional symbol of the role played.

Therefore, the specific characteristics of mothers taking on specific roles in relation to their children with intellectual disabilities made it possible to give them conventional names (terms) which combine the characteristics of the respondents. On this basis, group R1 was symbolically defined as "REBEL". For the mothers representing this group combined features which, on the basis of the collected material and synonyms of this term, presented them as persons such as: restless spirits, revolutionaries, warriors, opponents, activists, adversaries, polemics or non-conformists, combining the most characteristic features of the subjects.

The next role, R2, was called "RATIONALIST". In this case, the analysis of the statements of the examined mothers seems to clearly indicate their rational approach to life. This kind of traits concern people who stand firmly on the ground, think soberly, pragmatically, practically and realistically. The characteristics of this group of examined mothers are the most distinct.

The most difficult task was to find a name for the R3 role. The traits that the mothers belonging to this group of subjects had in the dictionary of synonyms were described very pejoratively, e.g.: a storyteller, a double dealer, a hypocrite, a manipulator, a mystifier, but also an insincere person or an actor - a declaimer. Therefore, when defining the image of the examined mothers, it was assumed that the most adequate label, combining the features of the examined mothers was «SHAM» eloquently defining their assumed role.

The last was the role of R4, identified in the term "RESOURCEFUL". This "resourceful" character reveals both the specific vocabulary of the mothers constituting this group of subjects and the aims (motivations) of their verbal communication. Among the synonyms 
of the use of this term there are also such terms as: energetic, effective, tireless or caring, but also cunning, able to win what she wants (even by blatancy or begging). Thus drawing a picture of the characteristics of the examined mothers.

\section{CHARACTERISTICS OF THE ASSUMED ROLES OF MOTHERS OF CHILDREN WITH INTELLECTUAL DISABILITIES BASED ON THE EMPATHY MAP}

It also seemed interesting to complement the terms used above to characterise the particular roles of mothers of children with intellectual disabilities. Based on the analysis of a set of unfinished sentences, modelled on the so-called empathy map used in the Design Thinking Method by David Kelley, applied for a deep understanding of the needs, problems and motivations of the subjects, so-called "walking in the shoes of the examined person". A subjective selection of the most characteristic statements of the mothers representing the particular roles is presented in the table below (Table 2).

Table 2. Subjective selection of the mothers' most characteristic statements

\begin{tabular}{|c|c|c|c|c|}
\hline \multirow{2}{*}{$\begin{array}{l}\text { Category } \\
\text { of question }\end{array}$} & \multicolumn{4}{|c|}{ MOTHERS' RESPONSES BY TYPE } \\
\hline & «REBEL» & «RATIONALIST» & «SHAM» & «RESOURCEFUL» \\
\hline $\begin{array}{l}\text { My biggest pain in } \\
\text { life is ... }\end{array}$ & $\begin{array}{l}\text { - my child's illness. } \\
\text { - my child's disability. } \\
\text { - a sick child. } \\
\text { - my daughter's } \\
\text { - } \text { mealth. } \\
\text { - } \text { defect. } \\
\text { - Prader-Willi } \\
\text { - syndrome. } \\
\text { - tha state support. } \\
\text { people in power are } \\
\text { - thterested in us. } \\
\text { - too short a day. }\end{array}$ & $\begin{array}{l}\text { - my child's } \\
\text { disability. } \\
\text { no certain } \\
\text { possibilities. }\end{array}$ & - none. & $\begin{array}{l}\text { - that I am alive. } \\
\text { - the sorrows of my } \\
\text { child. } \\
\text { - that I'm not brave } \\
\text { enough. } \\
\text { - house renovation. } \\
\text { - Julia's dad. } \\
\text { - that I'm raising my } \\
\text { child alone. } \\
\text { - the shortage of } \\
\text { money. } \\
\text { - that I can't cure } \\
\text { my child. }\end{array}$ \\
\hline I am most afraid ... & $\begin{array}{l}\text { - of a situation in } \\
\text { which Maciek's } \\
\text { siblings will be } \\
\text { burdened with } \\
\text { taking care of him. } \\
\text { - that my daughter } \\
\text { will be left alone. } \\
\text { - whether my son } \\
\text { will be able to cope } \\
\text { after my death. } \\
\text { - of the future of } \\
\text { such children. } \\
\text { - of what will } \\
\text { happen to our } \\
\text { children. } \\
\text { of a war. }\end{array}$ & $\begin{array}{l}\text { - of my child's } \\
\text { illness. } \\
\text { - that I won't be } \\
\text { able to prepare } \\
\text { my son for the } \\
\text { moment I die. }\end{array}$ & $\begin{array}{l}\text { - of the future. } \\
\text { - of my son's future. } \\
\text { whether I can } \\
\text { take care of my } \\
\text { daughter in good } \\
\text { health. } \\
\text { - of the society's } \\
\text { assessment of my } \\
\text { child. }\end{array}$ & $\begin{array}{l}\text { - of old age. } \\
\text { - of loneliness. } \\
\text { - of a disease. } \\
\text { - of death. } \\
\text { - of worsening of } \\
\text { the disease. } \\
\text { - she won't even } \\
\text { have half the care } \\
\text { I give her. } \\
\text { - that my son will } \\
\text { be alone when I'm } \\
\text { gone. } \\
\text { - of an accident. }\end{array}$ \\
\hline I'm nervous about ... & $\begin{array}{l}\text { - people's pettiness, } \\
\text { egocentricity. } \\
\text { - no care for the } \\
\text { environment. } \\
\text { - bureaucracy and } \\
\text { slow driving. } \\
\text { - my powerlessness. }\end{array}$ & $\begin{array}{l}\text { - the way my } \\
\text { daughter is taught. } \\
\text { - no forbearance } \\
\text { from people. }\end{array}$ & $\begin{array}{l}\text { - nothing. } \\
\text { - that people judge } \\
\text { before they know } \\
\text { a child's potential. } \\
\text { - my son's } \\
\text { behaviour. } \\
\text { - the noise the } \\
\text { children make. } \\
\text { - human jealousy. } \\
\text { - aggression and } \\
\text { callousness. } \\
\text { - that people are } \\
\text { staring. } \\
\text { - the looks of } \\
\text { people. }\end{array}$ & $\begin{array}{l}\text { - helplessness. } \\
\text { - human } \\
\text { indifference. } \\
\text { - that I have no } \\
\text { money. }\end{array}$ \\
\hline $\begin{array}{l}\text { My greatest dream } \\
\text { is ... }\end{array}$ & $\begin{array}{l}\text { - to travel freely. } \\
\text { - to establish a } \\
\text { foundation. }\end{array}$ & $\begin{array}{l}\text { - a long journey. } \\
\text { - there are several, } \\
\text { Paris, Venice or } \\
\text { (illegible). } \\
\text { - a rest. }\end{array}$ & $\begin{array}{l}\text { - seeing my son } \\
\text { speak. } \\
\text { - a peaceful old age. } \\
\text { - to get away as far } \\
\text { away as possible. } \\
\text { - to win the lottery. }\end{array}$ & $\begin{array}{l}\text { - seeing my son } \\
\text { healthy. } \\
\text { - to see her walking } \\
\text { on her feet. } \\
\text { - my daughter's } \\
\text { happiness. } \\
\text { - my son's happiness } \\
\text { - to go on a trip abroad. }\end{array}$ \\
\hline
\end{tabular}




\begin{tabular}{|c|c|c|c|c|}
\hline \multirow{2}{*}{$\begin{array}{l}\text { Category } \\
\text { of question }\end{array}$} & \multicolumn{4}{|c|}{ MOTHERS' RESPONSES BY TYPE } \\
\hline & «REBEL» & «RATIONALIST» & «SHAM» & «RESOURCEFUL» \\
\hline $\begin{array}{l}\text { The values that } \\
\text { guide me in life } \\
\text { are ... }\end{array}$ & $\begin{array}{l}\text { - love and helping } \\
\text { other people. } \\
\text { openness, } \\
\text { tolerance, } \\
\text { decency. }\end{array}$ & $\begin{array}{l}\text { - honesty, respect, } \\
\text { wisdom. } \\
\text { - ethical values. } \\
\text { - catholic religion, } \\
\text { principles and } \\
\text { values. } \\
\text { - perseverance and } \\
\text { patience. } \\
\text { - the good that } \\
\text { comes back. }\end{array}$ & $\begin{array}{l}\text { - love and sincerity. } \\
\text { - love. }\end{array}$ & $\begin{array}{l}\text { - } \text { sincerity. } \\
\text { - goodness, } \\
\text { independence. } \\
\text { - faith, hope, love, } \\
\text { sincerity. } \\
\text { - diligence and } \\
\text { telling yourself the } \\
\text { truth. }\end{array}$ \\
\hline $\begin{array}{l}\text { The most important } \\
\text { rule in life is ... }\end{array}$ & $\begin{array}{l}\text { - "what goes around } \\
\text { comes around". }\end{array}$ & $\begin{array}{l}\text { - stability, strength, } \\
\text { dutifulness. } \\
\text { - not to be ashamed } \\
\text { of your actions. } \\
\text { - not to look back or } \\
\text { hurt others. }\end{array}$ & $\begin{array}{l}\text { - to be good to } \\
\text { other people. }\end{array}$ & $\begin{array}{l}\text { - not to give up. } \\
\text { - " "whutual support. } \\
\text { comes around". }\end{array}$ \\
\hline My life goal is ... & $\begin{array}{l}\text { - to raise children to } \\
\text { be good people. }\end{array}$ & $\begin{array}{l}\text { - to progress } \\
\text { through life. } \\
\text { - to survive. } \\
\text { - there are many. }\end{array}$ & $\begin{array}{l}\text { - the happiness of } \\
\text { my children. } \\
\text { - the health of my } \\
\text { family. } \\
\text { - making dreams } \\
\text { come true. }\end{array}$ & $\begin{array}{l}\text { - to raise my } \\
\text { children as well as } \\
\text { possible. } \\
\text { - to find an } \\
\text { occupational } \\
\text { therapy workshop } \\
\text { for my daughter. } \\
\text { - to live long. }\end{array}$ \\
\hline $\begin{array}{l}\text { What I need most } \\
\text { is ... }\end{array}$ & $\begin{array}{l}\text { - loving people. } \\
\text { - the money to } \\
\text { start. }\end{array}$ & $\begin{array}{l}\text { - peace and } \\
\text { strength. } \\
\text { - a rest. } \\
\text { - purposeful, } \\
\text { reasonable people. }\end{array}$ & $\begin{array}{l}\text { - security. } \\
\text { - consolation. } \\
\text { - peace. } \\
\text { - support from my } \\
\text { husband. }\end{array}$ & $\begin{array}{l}\text { - professional help. } \\
\text { - financial support. } \\
\text { - peace and greater } \\
\text { earnings. }\end{array}$ \\
\hline $\begin{array}{l}\text { My greatest desire } \\
\text { is ... }\end{array}$ & $\begin{array}{l}\text { - to provide our } \\
\text { children with } \\
\text { systemic care }\end{array}$ & $\begin{array}{l}\text { - the health of my } \\
\text { children. } \\
\text { - not to worry about } \\
\text { whether I have } \\
\text { enough money to } \\
\text { live on. } \\
\text { - to rest completely. }\end{array}$ & $\begin{array}{l}\text { - to have a healthy } \\
\text { family. } \\
\text { - a miracle to } \\
\text { happen. } \\
\text { - to live outside the } \\
\text { city. }\end{array}$ & $\begin{array}{l}\text { - to give my son a } \\
\text { good life. } \\
\text { - seeing the children } \\
\text { succeed. }\end{array}$ \\
\hline $\begin{array}{l}\text { Around me I can } \\
\text { see... }\end{array}$ & $\begin{array}{l}\text { - my parents, } \\
\text { children, husband, } \\
\text { friends. } \\
\text { - nature. }\end{array}$ & $\begin{array}{l}\text { good and bad } \\
\text { people, happiness } \\
\text { and suffering. } \\
\text { - everyday life. }\end{array}$ & $\begin{array}{l}\text { - aggression, anger } \\
\text { of busy people. } \\
\text { - the world. } \\
\text { - people. }\end{array}$ & $\begin{array}{l}\text { - a lot of good. } \\
\text { - a lot of evil and } \\
\text { hate. }\end{array}$ \\
\hline My thoughts ... & $\begin{array}{l}\text { - are going beyond } \\
\text { the area in which } \\
\text { they operate on a } \\
\text { daily basis. } \\
\text { - are hustling full of } \\
\text { ideas. } \\
\text { - are rushing } \\
\text { forward. }\end{array}$ & $\begin{array}{l}\text { - are revolving } \\
\text { around my } \\
\text { daughter, her life } \\
\text { and happiness. } \\
\text { - are revolving } \\
\text { around my family. }\end{array}$ & $\begin{array}{l}\text { - are always with } \\
\text { my son. } \\
\text { - are only mine. } \\
\text { - are dark. } \\
\text { - are positive. }\end{array}$ & $\begin{array}{l}\text { - go crazy. } \\
\text { - are focused on } \\
\text { what I do. }\end{array}$ \\
\hline I feel like ... & $\begin{array}{l}\text { - I can do something } \\
\text { else. } \\
\text { - I'm needed. } \\
\text { - I'm already tired. } \\
\text { - I go crazy } \\
\text { sometimes. }\end{array}$ & $\begin{array}{l}\text { - I have to count on } \\
\text { myself in life. } \\
\text { - sometimes l'm fed } \\
\text { up with my life. }\end{array}$ & $\begin{array}{l}\text { - I'm living up to my } \\
\text { values. } \\
\text { - I'm fulfilled. } \\
\text { - I'm happy. } \\
\text { - I'm often sad. } \\
\text { - I'm weak. } \\
\text { - I'm a good mum. } \\
\text { - I'm happy and } \\
\text { fulfilled. }\end{array}$ & $\begin{array}{l}\text { - I can't do it } \\
\text { sometimes. } \\
\text { - it's gonna be okay. } \\
\text { - I'm making my } \\
\text { baby happy. } \\
\text { - I'm getting older } \\
\text { and I have so } \\
\text { much to do. }\end{array}$ \\
\hline Most often I hear ... & $\begin{array}{l}\text { - how good a man I } \\
\text { am. } \\
\text { - others complaining } \\
\text { about ... } \\
\text { - "you can do it". }\end{array}$ & $\begin{array}{l}\text { - "I love you" from } \\
\text { my daughter's } \\
\text { mouth. } \\
\text { - that I am strong. } \\
\text { - that others feel } \\
\text { good when I' m } \\
\text { with them. }\end{array}$ & $\begin{array}{l}\text { - something about } \\
\text { beauty. } \\
\text { - "good morning". } \\
\text { - the word "no" }\end{array}$ & $\begin{array}{l}\text { - "mum". } \\
\text { - my child's voice. } \\
\text { - different things. } \\
\text { - that things will get } \\
\text { better sooner or } \\
\text { later. } \\
\text { - that I am able to } \\
\text { cope in life. } \\
\text { - that my son is } \\
\text { healthy, and I } \\
\text { made up his illness } \\
\text { because he's } \\
\text { physically healthy. }\end{array}$ \\
\hline My life is ... & $\begin{array}{l}\text { - a constant } \\
\text { fulfilment } \\
\text { of duties, } \\
\text { expectations, } \\
\text { tasks. }\end{array}$ & $\begin{array}{l}\text { - not a fairy tale, } \\
\text { but it's very good. } \\
\text { - "here today, gone } \\
\text { tomorrow". }\end{array}$ & $\begin{array}{l}\text { - a box full of } \\
\text { surprises. } \\
\text { - an adventure. } \\
\text { - my family. }\end{array}$ & $\begin{array}{l}\text { - raising children. } \\
\text { - my family. } \\
\text { - constantly coping } \\
\text { with everyday life. }\end{array}$ \\
\hline
\end{tabular}




\begin{tabular}{|c|c|c|c|c|}
\hline \multirow{2}{*}{$\begin{array}{l}\text { Category } \\
\text { of question }\end{array}$} & \multicolumn{4}{|c|}{ MOTHERS' RESPONSES BY TYPE } \\
\hline & «REBEL» & «RATIONALIST» & «SHAM» & «RESOURCEFUL» \\
\hline & $\begin{array}{l}\text { - a constant } \\
\text { struggle. } \\
\text { - fighting for my } \\
\text { daughter's health. }\end{array}$ & $\begin{array}{l}\text { - happiness and } \\
\text { suffering. } \\
\text { - labour }\end{array}$ & $\begin{array}{l}\text { - monotony. } \\
\text { a chapter of } \\
\text { accidents. }\end{array}$ & \\
\hline As a woman ... & $\begin{array}{l}\text { - I feel that this } \\
\text { sphere is empty. } \\
\text { - I am unsatisfied } \\
\text { and sometimes } \\
\text { angry. } \\
\text { - I feel undervalued. } \\
\text { - I'm close to } \\
\text { feminism. }\end{array}$ & $\begin{array}{l}\text { - I'm proud of } \\
\text { myself. } \\
\text { - I am valuable. } \\
\text { - I try to keep myself } \\
\text { in mind. } \\
\text { - I'm open to new } \\
\text { things, I don't } \\
\text { close myself off } \\
\text { from the world. }\end{array}$ & $\begin{array}{l}\text { - I'm busy. } \\
\text { - I'm fulfilled. } \\
\text { - I don't like myself. } \\
\text { - I feel lost. }\end{array}$ & $\begin{array}{l}\text { - I'm good. } \\
\text { - I fulfil myself. } \\
\text { - I'm not attractive. }\end{array}$ \\
\hline As a mother ... & $\begin{array}{l}\text { - I'm like a lioness } \\
\text { protecting her } \\
\text { offspring. } \\
\text { - I'm fulfilled. }\end{array}$ & $\begin{array}{l}\text { - I feel fulfilled and } \\
\text { responsible for my } \\
\text { son's life. } \\
\text { - I feel fulfilled. } \\
\text { - I will do my best } \\
\text { to make my child } \\
\text { happy. } \\
\text { - I still have a lot to } \\
\text { do. } \\
\text { - I feel I have } \\
\text { a mission to } \\
\text { complete. } \\
\text { - I like my children. } \\
\text { - I don't feel } \\
\text { completely } \\
\text { satisfied I want a } \\
\text { third child. }\end{array}$ & $\begin{array}{l}\text { - I'm trying to meet } \\
\text { my child's needs }\end{array}$ & $\begin{array}{l}\text { - I'm calm. } \\
\text { - I feel fulfilled. } \\
\text { - I'm an ordinary } \\
\text { person. } \\
\text { - I feel responsible } \\
\text { and happy. } \\
\text { - I love my daughter. } \\
\text { - not all my dreams } \\
\text { have come true } \\
\text { for my children } \\
\text { because of the } \\
\text { alcoholic and lack } \\
\text { of money. }\end{array}$ \\
\hline
\end{tabular}

Source: own elaboration

On this basis, the analysis of unfinished sentences of the mothers of children with intellectual disabilities representing group R1, conventionally referred to as "REBEL", makes it possible to draw a picture of the respondents in which they appear to take a critical attitude, for example, indicating negligence on the part of the authorities/state in respect of the interest in the fate of their children. The surveyed mothers are most concerned about the future of their children with intellectual disabilities, that is, what will happen to them when they die. Their concerns not only focus on the specific fate of their son or daughter, but are more common, as an expression of concern for the overall fate of "such children". In addition, the surveyed mothers are afraid of the thought that in the future they will somehow condemn their healthy children to care for sick siblings. In this regard, their "discomfort" is enormous because, on the one hand, they are aware of the difficulties of caring for a son or daughter with intellectual disabilities, and on the other hand, as can only be presumed, they consider the ethics of entrusting "such an inheritance" to healthy children whose happy life "without burden" also is in their hearts. What is extremely interesting, the fears of mothers representing this group of respondents also include those related to the feeling of military threats the possible consequences of which (even if only indirect) could probably worsen their already difficult situation (e.g. more expensive credits, more expensive fuel and thus food, medicines etc.). The fear of war as a choice of answers of the examined mothers representing this group was not isolated. This global thinking is also evidenced by the need to take care of the natural environment and thus noting the shortcomings in this area. Similarly, it is signalled that other people focus exclusively on themselves and their particular interests or matters, which, as they prove, is often the reason for their "rebellion". They may also find it a serious burden to be aware of their own powerlessness. This is the case for those who both feel "too small", "too quiet" to be able to count on the attention of others, from whom they would only expect the proverbial offering of their hand, and those who are aware of their own potential which is limited by the fact (in this case) of raising a child with intellectual disability. The dreams of the "rebel" mothers are connected with the need to travel and thus to rest, to change their perspective, to concentrate on pleasant and carefree things. This kind of need concerned many mothers in this group. Especially 
since many of them complained about fatigue not only in the physical aspect ("I'm already tired") but also in the mental aspect ("I go crazy sometimes"). The above results from fulfilling everyday, difficult duties, "tasks", as well as the "struggle for ...", which, as we know, is associated with an overwhelming concentration of strength, and then the need for rest and regeneration which, as you can guess, the examined mothers cannot always afford. Their dreams are also aimed at a more measurable goal, such as "establishing a foundation" whose primary goal may be to make their dreams of improving the fate of their children with intellectual disabilities a reality, which is also linked to many adversities, difficulties resulting from, for example, the lack of "the money to start" or "too short a day". In addition to the values that are typical and thus also professed by many people, such as love, the surveyed mothers emphasize the willingness to help others, openness and tolerance, which in a way sets them in the direction of "towards people", "together with people". This thesis is confirmed both by their life's principles ("what goes around comes around") and by their declared needs which prove their desire to surround themselves with "loving people", children, family, and to be with their husband/partner. However, this kind of need seems to be the only thing that remains for many of them. This can be seen in the way they perceive themselves as women: "unfulfilled, undervalued, meaningless" (in the sense of: not perceiving their own femininity, as well as the fact of not perceiving it by others, e.g. a husband/partner). They often consider their femininity in the misunderstood feminist movement, superficially painting the image of women as strong and independent people, who do not need love, tenderness, and men taking care of them. A characteristic feature of this group of surveyed mothers is the life goal they have set for themselves, namely to "raise their children to be good people", which during the research was not just an individual hint, as was their greatest desire, focusing on "providing our children with systemic care". They are "like lionesses protecting their offspring", which in the case of mothers of children with intellectual disabilities seems significant because their children will never fully become "adults", independent, able to organise their private and professional lives, etc., thus placing the mothers in a constant readiness to protect, fight and care for their fate, also - and perhaps above all - in the future. However, their thinking on this issue is symptomatic of this group of respondents, because they do not focus exclusively on improving their children's fate. They care about the welfare of other children with intellectual disabilities or people in general, which proves their more global thinking, openness or need to "be there for others". The "hustle of thoughts", "thoughts full of ideas", "rushing forward" may also be disturbing for this group of mothers. Only seemingly, in some cases, it may appear to be a positive value, testifying to their creativity and will to fight. It can be dangerous not to meet them, especially when they lose a battle and their dream goal is not achieved. Burning out, which can occur as a result of many lost battles, heated up by the incriminating awareness that "I'm needed", or by the words heard from loved ones, "you can do it", can consequently become a reason for their destruction.

The image of the mothers representing the R2 group, symbolically defined as "RATIONALIST", shows them as people who have a rational approach to life, confirming that this group of subjects was correctly defined. Their rational approach to life is evidenced by statements indicating that they perceive it in terms of "here today, gone tomorrow", "happiness and suffering", allowing them to sketch out their image as people who approach life rationally. Their rationalism of thinking about life on the one hand can inspire optimism, exemplified by the words of one of the mothers: "my life is not a fairy tale, but it is good". On the other hand, they can prove that they are constantly considering black scenarios, as well as being in constant readiness for something bad that may still happen in their lives, e.g. worsening of their child's condition or fearing "that I won't be able to prepare my son for the moment I die". Their thoughts still "are revolving around my family". As mothers, they are aware of their own transitoriness and, consequently, of the inevitability of leaving their child unaccompanied, as well as a constant fear of something that would threaten the 
existence of their child or themselves. Their life goal is mainly to "survive", to "progress through life" in full awareness of the fact that "they have to count only on themselves". Then they need not only extra strength, but also rest, which they cannot always expect. It should be assumed that this is not just about some short-term relaxation, but the need for total rest, the so-called "reset", because sometimes they are "fed up with their lives" and the desired rest would seem to provide them with a fresh and, of course, rational view of their lives, especially since a large number of them are also professionally active. However, this unspeakable need may never be met for the group of mothers described. The environment perceives them as strong people, which is undoubtedly true, but blurring their real image, for example, in those moments of their lives when they feel depressed, expecting support and help, which - as we can only assume - often does not happen. It seems that the mask of a woman who is strong, rational, hard on the ground can often cover up their true image, especially as many of them indicated that they "see people around them who don't always understand them", needing those "purposeful" and "reasonable" ones (implicitly: just like them - specific and rational to life). An interesting picture of the examined mothers qualified to the group of "rationalists" can be read from the analysis of values they follow in life. In this respect, we can say that these are mothers with the most stable axiological pillar. It is dominated by ethical values, both universal and Catholic. Many of them pointed to the religion the principles of which are also manifested in their behaviour: "not to harm others", "not to be ashamed of your actions", "the good that comes back", which are examples of life mottos. However, the values that many of them have pointed out are significant for this group of mothers. These include: "perseverance", "strength", "patience", "stability", "dutifulness" which most reflect the image of the subjects. The "rationalist" mothers show a kind of tendency to master every aspect of their lives, and thus of the lives of their children with intellectual disabilities, and therefore an unquestionable source of their stress is the problems associated with the incompetent "way of teaching their children". Mothers who have signalled the problem in this or similar ways are aware of both the shortcomings and the educational possibilities of their children who sometimes do not encounter understanding from teachers or educators. This is due to "people's lack of understanding", resulting from a lack of desire to understand their real problems. As mothers, most of them feel fulfilled, although some of them lack e.g. "a third child", which is significant for this group of respondents, where statistically most mothers have three or more children. A disturbing element of their characteristics is the feeling that they still have many difficult tasks ahead of them. In practice, this can mean a lack of satisfaction with past life, a lack of joy and rejoicing in minor successes because of the feeling of "walking on thin ice", or because of the need to prepare for every scenario that their future may bring. It also seems that the sense of "mission they have to accomplish" can open them up more to the future than to the present day, making them, despite their rational approach to life, set themselves goals that are too distant or too demanding, without enjoying the small successes they undoubtedly achieve on a daily basis.

The hermeneutical analysis of the unfinished sentences of the R3 group, with the conventional term "SHAM", seems to be the most difficult. It is not infrequent that the statements of mothers representing this group of respondents differ, which would be understandable as they come from 25 representatives. However, individual mothers from this group of subjects build a dichotomous picture of themselves through their statements, e.g. the same mother writes that "her greatest life's pain is constant failure" (implicitly: nothing works for me), adding in the next one that "she feels happy and fulfilled", which makes her deny herself somewhat. There are many such examples, which seems to be a characteristic feature of the "sham" mothers. Another characteristic feature of this group of respondents is, firstly, shorter statements. Secondly, what seems to be worth emphasizing, utterances which somehow "quench" the discussion, not allowing one to look into the "inside" of the examined person. Typical and yet not isolated examples include, 
e.g. the complement "none" (implicitly: I have no pain in life) in response to "My biggest pain in life is ..." or the complement "nothing" (implicitly: nothing annoys me, everything is in perfect order) in response to "I'm nervous about ..." which, as can only be assumed, build a false - virtual image of the subjects. An example of building an apparent image of oneself and one's life is the statement of a mother for whom her life is "a box full of surprises". This does not mean that a mother of a child with intellectual disability cannot lead an interesting life. It seems, however, that this statement is inadequate, fitting more to "a celebrity receiving gifts" than to a mother whose main activity is dedicated to a child with intellectual disability, which seems to be a wishful thinking of her life. However, there is no doubt that the source of stress for the surveyed mothers are concerns about the future, especially those related to the future of their children and whether they themselves will be able to function well enough in the future to support their children with intellectual disabilities. It is also characteristic for this group of examined mothers that they pay too much attention to others' opinions. It seems that the "sham" mothers would prefer to present themselves to society in a different way, from the better side, to present their own vision of themselves, their children, or their family. In reality, however, they collide with the fact that "people are staring" (implicitly: paying special attention to these attributes which they would prefer to conceal, not to show outside e.g. "son's behaviour"). The surveyed mothers pay special attention to "people's looks" and their judgements (implicitly: negative in the mothers' judgements), assuming in advance that these people are "jealous", "aggressive", or "devoid of feelings". Among the greatest dreams of the surveyed mothers are those related to making up for the deficiencies of their children resulting from disability, e.g. "seeing my son speak" and the vision of their own peaceful old age. Their thinking on the issue in question often takes the form of "magical desires and dreams" in which they expect "a miracle to happen" or a "to win the lottery", which in both cases would, implicitly, significantly change their fate. In the first one, it would probably be having a healthy child like other children who wouldn't catch the eyes of strangers or a generally healthy part of the family. In the latter case, a large injection of cash would divert attention away from the real problems they have with their children with intellectual disabilities, allow them to arrange their lives in a different way, perhaps solving many existential problems, as well as those related to the provision of extensive care and assistance to their children with disability, ensuring their future. It seems that through their statements the examined mothers show a need to escape. One of its forms is non-verbalised, read between the lines as an escape from the true self. The second one indicates directly the need to e.g. "live outside the city", which in their case can be read as a need to hide from the world, or directly "run away as far as possible". Both exemplifications may be examples of a serious burden resulting, firstly, from an internal need to keep up appearances and, secondly, as can only be assumed, from the unrealistic nature of their dreams. Love is one of the greatest values of this group of surveyed mothers, as indicated by almost the entire population. Another value, also not isolated, is sincerity which seems to be an alien value to the subjects themselves. The needs of these mothers, in addition to those indicated above, are focused on safety and peace the provision of which lies with the husband/partner, since the vast majority of them do not work. It seems that only in some cases the examined mothers have revealed their true face. Under the guise of a fulfilled and happy woman, which does not rule out these possibilities, there is - at least in the great majority of cases - a "weak" woman who is "sad", "dislikes herself", "bored with the monotony of her life", a mother whose real life goal is to "fulfil dreams" and "the needs of her child". This is how a mother appears to have two faces: the one she presents at home, and the one she brings to the outside, keeping up appearances even towards herself as a woman ("sometimes I have dreams, then I think it's stupid to think about myself in my situation").

Mothers representing the role of R4, conventionally referred to as "RESOURCEFUL", present themselves as people who want the best for their children. However, their dreams 
and life's ills concerning this sphere take on a wishful thinking: "seeing my son healthy", "to see her walking on her feet", "my son's happiness and independence", "that I can't cure my child". Their desires, which unfortunately will not be fulfilled, may, on the one hand, be a source of their stress because they cannot solve these problems, and on the other hand, they appear to be a driving force for action on behalf of their children with intellectual disabilities. Among these are the simplest ones that mothers can deal with on their own, such as removing sadness from the faces of their children, through more practical ones such as "finding an occupational therapy workshop for my daughter", to the so-called "flagship ones" that most mothers aim for: "to raise my children as well as possible" or "to give my son a good life". The surveyed mothers are aware that there are obstacles in their path ("I'm not brave enough") and those related to financial shortcomings. It seems that the surveyed mothers approach these issues in a task-based manner, consistently pursuing their goals, constantly proving that they manage in life, which is confirmed by words heard from loved ones approving of their competence: "that I am able to cope in life". However, providing evidence of the accuracy of defining this group of mothers does not mean that they are self-sufficient in their resourceful actions. The representatives of this group openly admit that they need "professional help", "financial support" or "higher earnings" which, as further analysis of their statements proves, are often a reality for them. Generally speaking, one can say that the mothers belonging to this group are oriented towards cooperation and "mutual support" in which they probably see the source of their strength. In terms of the concerns they have, they present themselves in a typical way, like most mothers of children with intellectual disabilities. This is because they concern issues that can be looked at from the point of view of a child, e.g. "the worsening of the illness (implicitly: of the child), "providing (implicitly: to the child) care after (implicitly: her) death", etc., and from the point of view of mothers who e.g. are afraid of "their own death", accidents, illness, old age, loneliness, realising that their death, or being infirm will influence the quality of life of their children. Their concerns in this regard may also be a source of their stress. Another may be due to a lack of strength, fatigue, but also financial shortcomings, then they may say, "I can't do it sometimes". The principles they follow - "do not give up", or words they hear from their loved ones: "things will get better sooner or later" can be the strength for them to cope with the toughest moments. They can also be a cause that will inhibit their activity. The statement made by one of the mothers is worrying in this respect: "My biggest pain in life is [that] I am alive", which is evidence of experiencing so-called depressive moments, such as those of "that they're raising their children alone", "husband's/partner's alcoholism", or other family problems that hinder their functioning. Although in the spectrum of values they follow there are those typical of "faith, hope and love", almost all the mothers in this group of subjects indicated "sincerity" as the overriding value. This may indicate openness and the need to be fully aware of the nature of the problems that affect them and thus be more effective (resourceful) in overcoming them. They feel best in the role of mothers in which they are "fulfilled", "calm", loving their children with intellectual disabilities with a love that can be described in the good sense of the word as "ordinary", which can be interpreted, on the one hand, as concern for ensuring existence, wellbeing, satisfaction, and, on the other hand, as being a warm, sometimes indulgent, fully accepting mother like others for their children.

\section{DISCUSSION AND CONCLUSIONS}

The role of parents caring for children with intellectual disabilities has been the focus of many researchers $[20,21,9]$. However, observation of social life indicates that it is mainly mothers (without diminishing the significant role of fathers) who are involved in the daily care and upbringing of their children with intellectual disabilities. Hence, it was of interest to the author of this study to categorise and describe the roles that mothers of children with intellectual disabilities construct on the basis of their physical (somatic), 
psychological, personality characteristics and social conditions. The conducted research enabled identifying the most characteristic features of the roles played and grouping them into symbolic names: "rebel", "rationalist", "sham", "resourceful".

At this point it is worth asking what was the purpose of this assignment of mothers of children with disabilities to a particular group? Well, this division (even if not in a "pure" way, at least in a "mixed" way) based on the identification of the characteristic features of each role can be useful for the therapist who can quickly and precisely extract specific points of contact and use them in individual therapy dedicated to a specific mother of a child with an intellectual disability. A similar approach to therapeutic practice can be found in the work of Patterson and his colleagues at the Centre for Social Learning in Oregon $[22,23,24]$ who, more than 50 years ago, described the individual characteristics of patients undergoing therapeutic interventions, compiling a list of their specific traits and behaviours in a specially designed manual. On this basis, it seems that relying on ready-made material (the above description of characteristic features) shortens the process of therapeutic diagnosis by allowing the therapist to identify more important life topics that may be relevant to mothers participating in therapy, by allowing one to name them, discuss them, identify possible problems and try to identify opportunities for solving them, changing or modifying the role played [25]. A therapist knowing, for example, that the characteristics of a mother most closely match those of a "REBEL" mother, characterised by strength, courage, taking initiative, fighting for the interests of her child with intellectual disabilities, etc., can quickly predict that the consequence of this role is burnout, a sense of powerlessness or loneliness in one's own actions - the essence of the therapy dedicated to her. Knowing that a given mother can be assigned to the group "SHAM» whose life attitude indicates e.g. abnormal social relations, living on the one hand in constant fear, anxiety, guilt and shame, and on the other hand pretending to be happy and satisfied with her life. In fact, revealing its dichotomous functioning which can also be an important aspect of personalised therapy. A similar approach is widely described in therapeutic practice, for example in the Goldenberg family therapy manuals [26].

The characterisation made of the roles of mothers of children with intellectual disabilities can also be helpful for the mother to acquire an awareness of the role she performs. In this sense, therapeutic work dedicated to such a mother can confront the role she plays with others that may be in opposition to the leading one. The conflict, inhibiting the full realisation of the other roles, may become the reason (motive) for her therapy. The therapist's role in this aspect is to indicate the points of contact (conflicts) resulting from the role adopted by the mother of a child with intellectual disabilities in relation to the others, sketching an outline of the prognosis resulting from the implementation of the scenario chosen by her. For example, a mother whose traits most closely match those of a group conventionally termed "RATIONALIST" takes a rational approach to "organising life" for her child with an intellectual disability and has a strong sense of mission to be accomplished. Looking at the world from too distant a perspective, in order to anticipate possible dangers, to be prepared for rational solutions to unfavourable circumstances that may occur, the everyday reality may disappear. This knowledge may suggest that the therapist assess this condition and be helpful in identifying the characteristics of the other roles she plays in relation to her other children, life partner, employer or other significant people. Awareness of the role played by the mother will, in this case, make it possible to single out and name those qualities that stand in contrast to the other roles played by her, namely those without internal agreement, e.g. her lack of awareness of the emotional neglect of her other children or the deterioration of her partner relationships of which she was previously unaware or those which are in opposition to it, e.g. the chronic need to rest, to "reset", and consequently to make these needs real. Becoming self-aware of the role played by a mother of a child with an intellectual disability makes her an observer 
with different points of view and thus allows her to gain distance from it, which can be a turning point in therapy [27]. A similar position can be found in the work of the Ackerman Institute staff e.g. [28, 29] and in many more recent studies [30, 31].

Identifying the role played by a mother of a child with an intellectual disability, her narrative understanding can also be helpful when her characteristics most closely match those of mothers in the "RESOURCEFUL" group. On the surface, it would seem that there are no grounds for modifying the role of a mother who has dedicated her whole life, all her energy, all her actions, thinking, worries and fears to her child with an intellectual disability, for example, when struggling with financial problems, setting the happiness and well-being of her child as a goal, while at the same time thinking wishfully and unrealistically "that her son would be healthy", "that her daughter would walk on her feet". The fact is that this role does not require a categorical break with that most essential of values - her intellectually disabled child and her care for them. It is not possible to ask a mother to make her intellectually disabled child no longer an absolute value for her. However, in such a case, the therapist's task could be, for example, to empower the mother, to develop in her an attitude of readiness, to release in her the potential to absorb new values. In other words, if her attention is solely focused on her intellectually disabled child, who is of absolute value to her, while at the same time she struggles to cope with the problems of everyday life, it is the therapist's task to make her also turn towards something new, objectively meaningful, to open up to other people, to open up to the world. It is not a question of the mother ceasing to treat her intellectually disabled child as a value (this is impossible), but of opening up to new values as well, absorbing them in proportion. The adoption of new values, the desire for them, positively influences the shape of the role she has played so far as a mother of a child with an intellectual disability [32, 33, 34]. While accepting herself and acquiring the ability to maintain her self-esteem [27). Understanding her role will also allow her to rediscover herself, to love herself and to discover the meaning of her life, which will undoubtedly involve an improvement in the quality of her life despite the difficult situation in which she finds herself $[35,9]$.

\section{REFERENCES}

[1] Majewski T. Międzynarodowa Klasyfikacja Uszkodzeń, Niepełnosprawności i Upośledzeń - problemy i nowe propozycje [International Classification of Impairments, Disabilities and Handicaps - problems and new proposals]. Problemy Rehabilitacji Społecznej i Zawodowej. 1998;1:64-68. Polish.

[2] Waisbren SF. Parents' reactions after the birth of a developmentally disabled child. Am J Ment Defic. 1980;84(4):345-351.

[3] Twardowski A. Sytuacja rodzin dzieci niepełnosprawnych [The situation of families of disabled children]. In: Obuchowska I, editor. Dziecko niepełnosprawne w rodzinie [Disabled child in the family]. Warsaw: WSiP; 1999, 18-53. Polish.

[4] Baczała D. Niepełnosprawność intelektualna a kompetencje społeczne [Intellectual disability and social competences]. Toruń: UMK; 2002. Polish.

[5] Linna S, Piha J, Kumpulainen K, Tamminen T, Almqvist F. Psychiatric symptoms in children with intellectual disability. Europeean Child and Adoloscent Psychaiatry. 1999;8:77-82. doi: 10.1007/PL00010704

[6] Patrzykąt-Owczarek B. Problemy seksualności osób z głębszą niepełnosprawnością intelektualną [Sexuality problems of people with deeper intellectual disability]. In: Jodko A, editor. Tabu seksuologii [Taboo of sexology]. Warsaw: SWPS "Academica";2008, 165-176.

[7] Białas M. How should we treat the disabled and maladjusted people? - The example of the sexuality of the intellectually disabled person. In: Żółkowska T, Konopska L, eds. Special Pedagogy - conceptions and the reality. Disability - the contextuality of its meaning. Stettin: Print Group Daniel Krzanowski; 2009, 37-42.

[8] Białas M. Logoterapia matki zagrożonej in-validus dziecka. Człowiek - Niepełnosprawność - Społeczeństwo [Logotherapy of the mother at risk of in-validus of the child. Man - Disability - Society]. 2018;1(39):25-46. doi: 10.5604/01.3001.0012.2389. Polish.

[9] Białas M. Stres matek dzieci z niepełnosprawnością intelektualną Analiza - Diagnoza - Terapia [Stress of mothers of children with intellectual disability. Analysis - Diagnosis - Therapy]. Gdańsk: Wydawnictwo Uczelniane Akademii Wychowania Fizycznego i Sportu; 2020. Polish.

[10] Lohe M. Niepełnosprawne dziecko przyczyną małżeńskich konfliktów i kryzysu w związku [A disabled child is the cause of marital conflicts and a crisis in the relationship]. Wspólne Tematy. 2003;6:42-49. Polish.

[11] Gawęcka M. Niepełnosprawność dziecka witalizacją rodziny. Perspektywa dialektyki współuzależnienia [Child's disability as a vitalisation of the family. The perspective of the dialectic of codependency]. Białas M, editor. Specjalne potrzeby niepełnosprawnych [Special Needs of Disabled People]. Kraków: ARSON; 2011, 13-23. Polish. 
[12] Sekułowicz M. Problemy funkcjonowania matek i ojców dzieci z niepełnosprawnością: analiza narracji [Problems of the functioning of mothers and fathers of children with disabilities: narrative analysis]. In: Palak Z, Bujnowska A, Pawlak A, eds. Edukacyjne i rehabilitacyjne konteksty rozwoju osób z niepełnosprawnością w różnych okresach ich życia [Educational and rehabilitation contexts of the development of people with disabilities in different periods of their lives]. Lublin: UMCS; 2010; 47-67. Polish.

[13] Deutsch H. Stress, psychological defence mechanisms and the private world of the mentally retarded: applying psychotherapeutic concepts to rehabilitation. Psychiatr. Aspects Ment Retard. 1989;Rev. 8:25-30.

[14] Streeton R, Cooke M, Campbell J. Researching the reserchers: using a snowballing technique. Nurse Researcher 2004;12(1):35-46. doi: 10.7748/nr2004.07.12.1.35.c5929

[15] Bergman, MM. Hermeneutic Content Analysis. Textual and Audiovisual Analysis within a mixed methods framework. In Tashakkori A, Teddlie C, eds. Handbook of mixed methods in social \& behavioral research. London: Sage Publications; 2010, 379-396. doi: 10.4135/9781506335193.n16

[16] Razzouk R, Shute V. What is design thinking and why is it important? Review of Educational Research. 2012;82:330348. doi: 10.3102/0034654312457429

[17] Heiss J. Social roles. In: Rosenberg M, Turner RH, eds. Social psychology: Sociological perspectives. Washington: Transaction Publishers; 1990, 94-129. doi: 10.4324/9781315129723-4

[18] Warren SF, Brady NC. The role of material responsivity in the development of children with intellectual disabilities „Retard Dey Disabil Res Rev. 2007;13(4):330-338. doi: 10.1002/mrdd.20177

[19] Rimmerman A, Portowicz DJ. Analysis of resources and stress among parents of developmentally disabled children. Int J Rehabil Res. 1987;10:439-445.

[20] Rowbotham M, Carroll A, Cuskelly A. (2011): Mothers' and fathers' roles in caring for an adult child. Int J Disabil Develop Educ. 2011;3:223-240. doi: 10.1080/1034912X.2011.598396

[21] Camprichova-Gezova K. Fathers's and mothers's roles and their particularities in raising children. Acta Technologica Dubnicea. 2015;5(1):136-151. doi: 10.1515/atd-2015-0032

[22] Patterson GR, Reid J. Reciprocity and coercion: Two faces of social systems. In: Neuriinger C, Michael J, eds. Behavior modification in clinical psychology. New York: Appleton-Century-Crofts; 1970, 93-145.

[23] Patterson GR. Families: Application of social learning to family life. Champaign, IL: Research Press; 1971.

[24] Patterson GR, Weiss RL, Hops H. Training of marital skills. In: Leitenberg H, editor. Handbook of behaviour modification and behaviour therapy. New York: Prentice-Hall; 1976, 45-71.

[25] Zaborowski Z. Koncepcja pewności siebie. Studia Psychologica. 2002;3:119-131.

[26] Goldenberg I, Goldenberg H. Family therapy: An overviev. California: Wadsworth Inc. Bolmont; 1980.

[27] Chodkowska M. Socjopedagogiczne aspekty współpracy pedagoga specjalnego r rodzicami dziecka niepełnosprawnego [Socio-pedagogical aspects of cooperation of a special educator with parents of a disabled child]. In: Palak Z, editor. Pedagog specjalny w procesie edukacji, rehabilitacji i resocjalizacji [A special educator in the process of education, rehabilitation and rehabilitation]. Lublin: UMCS; 2008, 34-41. Polish.

[28] Papp P, Silverstein O, Cartter E. Family sculpting in preventive work - well families. Family Process. 1973;12:1972212. doi: 10.1111/j.1545-5300.1973.00197.x

[29] Papp P. The proces of change. Nev York: Guilford Press; 1983.

[30] Olubiński A. Rola społeczna a procesy socjalizacji i wychowania [The social role and the processes of socialization and upbringing]. Ruch prawniczy, ekonomiczny i socjologiczny. 1999;LII (2):267-284. Polish.

[31] Frankl EV. Psychotherapy and Existentialism. selected papers on logotherapy. New York: Paperback; 1985.

[32] Landy R. Role theory and te role method of drama therapy. W: D. R. Johnson, R. Emunah, Currenth aprroaches in drama therapy. Sprigfild-Illinois: Charles c Thomas -Publisher, ITD; 2009, 65-91.

[33] Frankl EV. Wola sensu. Założenia i zastosowania logoterapii [Will to make sense. Assumptions and applications of logotherapy]. Warszawa: Czarna Owca; 2010. Polish.

[34] Frankl EV. Człowiek w poszukiwaniu sensu. Głos nadziei z otchłani Holocaustu [A man in search of meaning. A voice of hope from the abyss of the Holocaust]. Warszawa: Czarna Owca; 2011. Polish.

[35] Wolicki M. Logoterapeutyczna koncepcja wychowania [Logotherapeutic concept of education]. Stalowa WolaSandomierz: Wydawnictwo Diecezjalne; 2007. Polish. 